Turyzm 2006, 16/1

\author{
Anna Danilewicz \\ Studium Doktoranckie \\ Geografii Spoleczno-Ekonomicznej i Geografii Fizycznej \\ Uniwersytetu Łódzkiego \\ 90-142 Łódż, ul. Kopcińskiego 31 \\ vitalis@wp.pl
}

\section{POJĘCIE SILVAREKREACJI I SILVATURYSTYKI ORAZ ICH MIEJSCE W TERMINOLOGII TURYSTYCZNEJ}

\section{'SILVA-RECREATION' \\ AND 'SILVA-TOURISM' AND THEIR PLACE IN TOURISM TERMINOLOGY}

Las towarzyszy czlowiekowi właściwie od początków jego istnienia i pełni ważną funkcję nie tylko w przyrodzie, ale też w życiu i gospodarce człowieka. Las jest również miejscem, które może być odwiedzane przez caly rok w celach wypoczynkowych. Środowisko leśne daje możliwość realizacji różnych form turystyki i wiele osób jest zdania, że pobyt w nim gwarantuje pełną regenerację sił, wpływa korzystnie na stan zdrowia i samopoczucia, a także umożliwia poprawę kondycji fizycznej. Niektórzy nazywają lasy „zieloną apteką", w literaturze francuskiej, traktującej o zjawisku wypoczynku w lesie, pojawiły się ponadto określenia „lasu uzdrawiającego”, „dotleniającego”, „odkurzającego”, „oczyszczającego”, „bakteriobójczego" i "tłumiącego" (GADANT 1987), a także nazwano go "zielonym muzeum” (KALAORA 1993).

Autorkę szczególnie interesują zagadnienia związane z wypoczynkiem w lesie. Zainteresowanie to ma charakter nie tylko emocjonalny, polegający m.in. na wyjazdach do lasu, ale również naukowy - jednym z jego wyników jest praca magisterska pt. Atrakcyjność turystyczna Lasów Panstwowych na Pomorzu Zachodnim, będąca zwieńczeniem pięcioletniego okresu studiów na kierunku geografia turyzmu i hotelarstwa na Uniwersytecie Łódzkim. Praca ta traktuje o tym, jakie jest środowisko przyrodnicze, a dokładniej środowisko leśne na Pomorzu Zachodnim, a także jaki wpływ wywierają lasy na życie ludzi w aspekcie spolecz-
The forest has accompanied the human race practically ever since it appeared on Earth, and plays an extremely important role not only in nature, but in human life and economy. It is also a place which can be visited all year round for recreational purposes. The forest environment offers an opportunity for various forms of tourism and many people believe that staying in a forest guarantees full regeneration, enhances health, as well as improving physical well being. Some call the forest a 'green pharmacy'; in the French literature on forest recreation, expressions like the healing, oxygenating, cleansing and purifying, forest have appeared (GADANT 1987). It has also been called a 'green museum' (KALAORA 1993).

The author is particularly interested in issues concerning recreation in the forest. This interest is not only emotionbased, involving trips to the forest, but also academic. It resulted in an MA thesis entitled 'The Tourist Attractiveness of State Forests in Western Pomerania', which completed the author's five-year study at the Department of Geography and Hotel Management at the University of Lodz. The thesis presents issues regarding the natural environment, or the forest environment to be precise, in 
nym i gospodarczym. Zasadniczym celem autorki była próba określenia, na czym polega atrakcyjność turystyczna lasów oraz jakie formy turystyki i wypoczynku można realizować w środowisku leśnym.

Lasy Polski są powszechnie postrzegane jako atrakcyjne miejsce wypoczynku. Nie wszyscy jednak zdają sobie sprawę $\mathrm{z}$ tego, że lasy w Polsce stanowia prawie jedną trzecia powierzchni calkowitej kraju, są powszechnie dostępne i uznawane za jedne z najpiękniejszych lasów kontynentu europejskiego. Na podstawie lektury dotyczącej historii lasów i leśnictwa można stwierdzić, że kwestia dostępności lasów dla ludności pojawiła się, odkąd zaczęto mówić o gospodarce leśnej i potrzebie jej ochrony. Zdaniem STOCKIEGo (2001) historia zorganizowanej turystyki i rekreacji w lasach sięga połowy XIX w., gdy zaczęto dokonywać podziału lasów na gospodarcze i przeznaczone do innych celów, w tym celów rekreacyjnych, np. funkcje rekreacyjne od wieków pelnią Puszcza Białowieska i Puszcza Kampinoska. We współczesnej, trwale zrównoważonej gospodarce leśnej, potrzeby człowieka, jego warunki życia i zdrowia, stawiane są na pierwszym miejscu. Jest to zatem taka gospodarka, w której, oprócz produkcji drewna i innych surowców, bardzo istotne jest zagwarantowanie realizacji pozaprodukcyjnych funkcji lasu - ochronnych i społecznych, w tym funkcji wypoczynkowych. W celu umożliwienia ludności wypoczynku na terenach leśnych a jednocześnie zadbania o ich stan, w rozdz. 5 ustawy o lasach znalazł się zapis dotyczący powszechności dostępu do lasu: „Lasy stanowiące własność Skarbu Państwa [...], są udostępniane dla ludności”. Należy przy tym podkreślić, że przebywanie w lesie wiąże się z przestrzeganiem obowiązujących przepisów, a także zasad prawidłowego zachowania się w tym środowisku.

Celem pracy jest zdefiniowanie pojęć silvarekreacji i silvaturystyki, a także próba przedstawienia ich związku z innymi pojęciami stosowanymi w naukach o turystyce. Pojęcia te zostały sformulowane podczas realizacji pracy magisterskiej i są wynikiem głębokich przemyśleń i wniosków autorki, popartych wnikliwą analizą literatury przedmiotu. Zauważono bowiem, że mimo różnorodności prac z zakresu turystyki, istnieje wyraźna luka w badaniach naukowych zjawiska wypoczynku w środowisku leśnym, jak również brak odpowiednich pojęć w terminologii turystycznej. Slownik języka polskiego (2006, s. 566) podaje, że definicja to: „określenie znaczenia pojęcia lub wyrażenia,
Western Pomerania, and the influence the forest has on life from a social and economic point of view. Its main aim was to attempt to define what constitutes the tourist attractiveness of forests, and what forms of tourism and recreation can be undertaken in a forest environment.

Polish forests are commonly seen as attractive for recreation. Not everybody, however, realizes that they cover almost one third of the country's total area, that they are generally available for public use and considered among the most beautiful in Europe. The history of forests and forestry makes it clear that the problem of their public availability has existed ever since the issue of a forest economy and its protection appeared. According to STOCKI (2001), the history of organized tourism and recreation in forests goes back to the middle of the $19^{\text {th }} \mathrm{c}$. when forests started to be divided into those used for economic and those for other purposes, including recreation. For example the Bialowieska and the Kampinoska Forests have performed a recreational function for centuries. In the contemporary, stable, forest economy, human needs and living and health conditions are given priority. Thus, it is an economy in which, apart from the exploitation of wood and other resources, it is also very important to maintain non-production functions i.e. conservational and social ones, including recreation. In order to enable people to rest in forest areas and at the same time to protect them, Section 5 of the Forest Act includes a clause regarding the common availability of forests: "State Forests (...) are open to the public". It must be stressed here that visiting a forest involves following certain regulations, as well as a behaviour code.

The aim of the article is to provide definitions of 'silva-recreation' and 'silvatourism', as well as to present their links to other concepts used in tourism-related subjects. Those two concepts emerged while the author was working on her MA thesis and are a result of a thorough consideration of the problem and a thorough analysis of the literature. It was observed that despite the variety of work on tourism, 
sprowadzające się zwykle do sprecyzowania jego treści i zorientowania się w jego zakresie, co ułatwia właściwe posługiwanie się wyrazem". Należy zatem w pierwszej kolejności nazwać i opisać dane zjawisko, aby było moźliwe znalezienie związków $\mathrm{z}$ innymi i przyporządkowanie go do podobnej grupy lub stworzenie zupełnie nowej.

Przegląd dostępnych pozycji literatury przedmiotu pozwala stwierdzić, że liczba definicji dotyczących turystyki i rekreacji jest znaczna, a każdy $\mathrm{z}$ badaczy zwraca szczególną uwagę na odmienny aspekt ich oddzialywania. Przytoczone zostana przede wszystkim te definicje, w których zwrócono uwagę na to, że omawiane zjawiska zachodza w określonej przestrzeni i oddziałuja na środowisko przyrodnicze. Wynika to $\mathrm{z}$ faktu, że zakres znaczeniowy pojęć: „silvarekreacja” i „silvaturystyka" jest związany z wypoczynkiem, który odbywa się w środowisku leśnym, będącym częścią środowiska przyrodniczego i wywierającym wplyw na otaczającą nas przestrzeń.

W świetle definicji WTO (Światowa Organizacja Turystyki), oficjalnie uznanych w statystykach międzynarodowych, turystyka obejmuje ogół dzialań ludzi, którzy podróżują i przebywają dla wypoczynku, w interesach $i$ innych celach przez nie więcej niż jeden rok bez przerwy w miejscach znajdujących się poza ich zwykłym otoczeniem (KOWALCZYK 1997). Rekreacja to sposób wykorzystania czasu wolnego lub działalność podjęta w czasie wolnym, która może obejmować również turystykę (MEDLIK 1995). W literaturze specjalistycznej przyjęto nadrzędność pojęcia „rekreacja” w stosunku do ,turystyka” - takie stanowisko przyjęli m.in. DRZEWIECKI (2001) oraz WARSZYŃSKA i JACKOWSKI (1979), a także równoznaczność pojęcia ,rekreacji” w stosunku do „wypoczynku”.

W ostatnich latach duże zainteresowanie zarówno wśród naukowców, jak i organizatorów, czy samych turystów, wzbudzają formy turystyki przyjaznej środowisku naturalnemu, realizowane na terenach wiejskich, $\mathrm{z}$ dala od wielkich miast czy zatłoczonych miejscowości turystycznych. Formy te są różnorodnie nazywane, definiowane i często mylone ze sobą lub stosowane zamiennie. Wprowadzono m.in. takie określenia, jak: turystyka alternatywna (alternative tourism), turystyka aktywna (active tourism), turystyka kwalifikowana i specjalistyczna, turystyka wiejska i turystyka na terenach wiejskich (rural tourism), agroturystyka, ekoturystyka, turystyka zrównoważona (sustainble tourism), a także turystyka: ekologiczna, proekologiczna, przyrodnicza (nature tourism), przyjazna there is a lack of research devoted to recreation in the forest environment, as well as of an appropriate terminology. According to the 'Dictionary of the Polish Language (Stownik języka polskiego, 2006, p. 566)', a definition is a description of the meaning of a word which usually comes down to presenting its precise contents and possible range to facilitate the appropriate use of the word. Therefore, first a given phenomenon should be named and described in order to find its links to others, place it in a group of similar items or create a new group.

In the light of WTO (World Tourist Organization) definitions, officially approved for international statistics, tourism includes all activities done by those who travel during holidays, on business and for other purposes for no longer than one year, in places other than their regular surroundings (KowALCZYK 1997). Recreation is a way of using free time or activities done in free time, which may also include tourism (MEDLIK 1995). In the literature the concept of recreation has been agreed to be superior to that of tourism (among others by DRZEWIECKI 2001, WARSZYŃSKA \& JACKOWSKI 1979).

In recent years academics, tourism organizers and tourists themselves have been greatly interested in the development of environmentally-friendly forms of tourism in rural areas, far from big cities or crowded tourist resorts. These forms are given different names and definitions and are often confused or used inappropriately. The following terms have appeared: alternative tourism, active tourism, tourism for special purposes, rural tourism, agrotourism, eco-tourism, sustainable tourism, as well as ecological tourism, nature tourism, green tourism, nature-based tourism, soft tourism, adjusted tourism, responsible tourism, adventure tourism, special interest tourism, or even 'ecoethno-tourism'.

Due to the vast variety of terms, attempts have been made to find one which would encompass all these forms. Authors who have dealt with this problem include SzWICHTENBERG (1998), DRZEWIECKI (2001) and ZARĘBA (2001). DrZe- 
środowisku, zielona (green tourism), oparta na przyrodzie (nature based tourism), lagodna (soft tourism), dostosowana, odpowiedzialna (responsible tourism), wspierająca, przygodowa (adventure tourism), specjalnych zainteresowań (special interest tourism), ekoetnoturystyka.

W związku ze znaczną różnorodnością określeń, w literaturze przedmiotu podjęto także próby znalezienia pojęcia nadrzędnego dla przedstawionych form turystyki. Zajmowali się tym m.in. SZWICHTENBERG (1998), DRZEWIECKI (2001) i ZARĘBA (2001). Drzewiecki uważa, że nadrzędnym pojęciem jest „turystyka alternatywna”, albowiem jest to taka forma turystyki, która preferuje bliski związek turystów ze społecznością miejscową, a zamiast intensywnego przeobrażania środowiska przez inwestycje infrastrukturalne - wykorzystywanie walorów regionów recepcyjnych oraz istniejącej zabudowy w taki sposób, aby w największym stopniu zachować środowisko przyrodnicze. Za turystykę alternatywną można zatem uznać każdą turystykę „małej skali”, wymagającą aktywnego uczestnictwa i postawy przyjaznej środowisku (DRZEWIECKI 2001).

Autorka opracowania nie podziela stanowiska Drzewieckiego. Uznano, że określenie turystki alternatywnej jest malo precyzyjne, a także nasuwa liczne wątpliwości i pytania, np. alternatywna do czego? co oznacza „bliski związek turystów ze społecznością miejscową"? kiedy możemy mówić o turystyce „małej skali” i gdzie znajduje się granica między turystyką ,dużej skali”? Przyjęto natomiast stanowiska pozostałych autorów, którzy za nadrzędne uznali pojęcia: „turystyka na terenach wiejskich” - A. Szwichtenberg i ,turystyka zrównoważona" - D. Zaręba. Zwrócono uwagę na fakt, że terminy te nie są jednoznaczne, ale można znaleźć między nimi część wspólną - obydwa uwzględniają związek turystyki z przestrzenią i środowiskiem przyrodniczym.

SZWICHTENBERG (1998) dokonal analizy sposobów pojmowania definicji turystyki wiejskiej w literaturze polskiej i zagranicznej. Autor nie podjąl się wprawdzie sformułowania własnej definicji turystyki wiejskiej, ale przedstawił obszerne zestawienie definicji turystyki wiejskiej i wyciagną interesujące wnioski. Dla autorki szczególnie cenny jest komentarz A. Szwichtenberga dotyczący podziału turystyki wg kryterium przestrzeni i skutków oddziaływania na środowisko przyrodnicze, a wprowadzonego przez BoGUCKIEGO, WoŹNIAKA i ZĄTEK (1995). Jego zdaniem środowisko pozamiejskie jest tym samym, co tereny wiejskie, a tu- wiecki believes that the superior concept is that of 'alternative tourism', because it favours close contacts between tourists and the local community, and instead of intensively transforming the environment by infrastructural investment, tourists benefit from the assets of reception regions and the existing buildings in a way which preserves the natural environment. Alternative tourism can be thus seen as any 'small scale' tourism which requires active participation and an environmentally-friendly attitude (DRZEWIECKI 2001).

The author of the article does not share the above viewpoint believing that the definition of alternative tourism is not sufficiently precise and raises many doubts and questions e.g. "What is it alternative to?', 'What does 'close contacts between tourists and local community' mean?', and 'When can we talk about 'small scale' tourism and where does the 'large scale' tourism begin?' The other authors' opinions, however, have been accepted. They state that 'rural tourism' (Szwichtenberg) and 'sustainable tourism' (Zaręba) are superior concepts, which, although not synonymous, have one part in common - they both incorporate the link between tourism, space and the natural environment.

SzWICHTENBERG (1998) has carried out an analysis of the ways the definition of rural tourism is presented in Polish and foreign literature. Although the author did not attempt to formulate his own definition, he presented a vast selection of definitions and came to interesting conclusions. This author particularly values his comment regarding the division of tourism according to spatial and environmental criteria introduced by BOGUCKI, WOŹNIAK \& ZATEK (1995). In Szwichtenberg's opinion, the non-urban environment is synonymous with rural areas, and rural tourism includes such forms as nature tourism, farm and summer country holiday tourism, and tourism in special recreational areas.

Sustainable tourism is defined as activity integrated with environmental protection and the creation of new attitudes and behaviour in tourists and tourism 
rystyka na terenach wiejskich obejmuje m.in. takie formy turystyki, jak: turystyka w przyrodzie, turystyka związana z wsią rolniczą i letniskową, a także turystyka na specjalnych terenach wypoczynkowych.

Turystyka zrównoważona jest definiowana w literaturze jako dzialanie zintegrowane $z$ celami ochrony przyrody, a także kształtowaniem nowych postaw i zachowań turystów oraz organizatorów ruchu turystycznego. Te nowe postawy winny być korzystne etycznie i spolecznie dla lokalnej ludności. Jest to integracja ruchu turystycznego ze spolecznością lokalną oraz życiem społeczno-gospodarczym rejonów koncentracji ruchu (GOLEMBSKI 2002).

ZARĘBA (2001) przedstawiła cele, mające zbliżyć turystykę do zasad ekorozwoju (rozwoju zrównoważonego). Turystyka, aby mogła być nazwana zrównoważoną, powinna wpływać na:

- propagowanie zdrowego i produktywnego sposobu życia w harmonii z przyrodą, kreowanie otwartości i tolerancji;

- zachowanie zasobów przyrody i ochronę rdzennej kultury spoleczności lokalnych;

- planowanie i kreowanie nowych źródeł dochodów ludności miejscowej;

- zmniejszenie ilości odpadów, oszczędność wody i energii;

- rozwój postaw proekologicznych;

- promowanie polityki otwartego systemu rynkowego w turystyce, wolnej wymiany usług turystycznych z respektowaniem zasad turystyki przyjaznej dla środowiska.

Ekorozwój można określić jako taki przebieg nieuchronnego i pożądanego rozwoju gospodarczego, który nie narusza w sposób istotny i nieodwracalny środowiska życia człowieka, nie doprowadza do degradacji biosfery i godzi prawa przyrody, ekonomii i kultury (GOŁEMBSKI 2002). Jest to taki rozwój gospodarczy, który zaspokaja potrzeby ekonomiczne, spoleczne i przestrzenne obecnie żyjących mieszkańców Ziemi, a jednocześnie uwzględnia konieczność zachowania wszystkich jej zasobów dla przyszłych pokoleń. $\mathrm{Za}$ najważniejszy dokument ujmujący pojęcie trwale zrównoważonego rozwoju uznano dokument AGENDA 21, zwany też Kartą Ziemi, podpisany przez przedstawicieli państw świata na Konferencji Narodów Zjednoczonych „Środowisko i Rozwój" (UNCD), zwanej też Szczytem Ziemi, która odbyła w Rio de Janeiro w 1992 r. O historycznym znaczeniu tego dokumentu pisali m.in. SZUJECKI (1997) i ZARĘBA (2001). organisers. These new attitudes should be ethically and socially beneficial for local inhabitants. It is an integration of tourism with the local community and the socio-economic life of tourist regions (GOlemBSKI 2002).

ZAREBA (2001) presented tasks which are to bring tourism closer to the principles of eco-development (sustainable development). In order to be called sustainable, tourism should encourage:

- the propagation of a healthy and productive way of living in harmony with nature, developing openness and tolerance;

- the preservation of natural resources and the protection of the culture of local communities;

- planning and the creation of new sources of income among the local population;

- a reduction in the amount of refuse, and the saving of water and energy;

- the development of pro-ecological attitudes;

- the promotion of the policy of an open market system in tourism, free exchange of tourist services, and respect for the principles of environmentallyfriendly tourism.

Eco-development can be defined as inevitable and necessary economic development that does not affect the environment in a significant or irreversible way, does not lead to the degradation of the biosphere, as well as reconciling the laws of nature, economics and culture (GolembSKI 2002). It is an economic development which satisfies the economic, social and spatial needs of the inhabitants of the Earth currently living, and at the same time does not disregard the necessity of preserving its resources for future generations. The most important document regarding the concept of permanently sustainable development is Agenda 21 signed by representatives from different countries at the 'Environment and Development' UN Conference (UNCD), also called the Earth Summit, which took place in Rio de Janeiro in 1992. The historic significance of this document has been discussed, among others, by SZUJECKI (1997) and ZARĘBA (2001). 
Za silvarekreację (od łac. silva - las) - rekreację na terenach leśnych - uznane zostały przez autorkę wszelkie formy aktywności realizowane w czasie wolnym, podczas pobytu w środowisku leśnym, które nie zaklócają naturalnego rytmu życia roślin i zwierząt, a ponadto przyczyniają się w znacznym stopniu do podniesienia poziomu świadomości ekologicznej w spoleczeństwie i poczucia potrzeby ochrony przyrody. Silvaturystyka, czyli turystyką na terenach leśnych, nazwano dzialania osób, które w czasie wolnym i przynajmniej przez jeden dzień, przebywają w środowisku leśnym, znajdującym się poza ich zwykłym otoczeniem, w celu wypoczynku, edukacji i rozwoju, realizacji zainteresowań i innych celach.

Określenie „silvarekreacja” jest nadrzędne dla „,silvaturystyki”, a wszelkie ich formy można zaliczyć do grupy działań turystycznych realizowanych zgodnie $\mathrm{z}$ zasadami ekorozwoju na terenach wiejskich, jak również w lasach miejskich i parkach leśnych. Jeśli wziąć pod uwagę kryterium przestrzeni, pojęciem nadrzędnym dla silvaturystyki i silvarekreacji będzie turystyka na terenach wiejskich; jeśli zaś kryterium oddziaływania na środowisko przyrodnicze - nadrzędne będzie pojęcie turystyki zrównoważonej. W przypadku pozostalych przedstawionych określeń turystyki związanej ze środowiskiem przyrodniczym, zauważono, że ich zasięgi znaczeniowe w dużej mierze pokrywają się z zakresami pojęć silvaturystyki i silvarekreacji.

W terminologii turystycznej istnieje wiele definicji dotyczących różnorodnych form turystyki, a także prób ich klasyfikacji. Może zatem pojawić się watpliwość, co do konieczności wprowadzenia dwóch nowych pojęć. Zdaniem autorki ich wprowadzenie jest uzasadnione, gdyż obejmuje całość zachowań turystycznych w środowisku leśnym.

Aktywności podejmowane w czasie wolnym w celu wypoczynku na terenach leśnych tworzą rozbudowaną i różnorodną grupę działalności. Walory przyrodnicze związane ze środowiskiem leśnym sprzyjają realizacji takich form silvarekreacji, jak: wczasy i kolonie letnie, obozy dla dzieci i młodzieży (stacjonarne, wędrowne, tzw. survival, czyli obozy przetrwania), polowania (w znaczeniu dosłownym, jak i związane z tzw. bezkrwawymi łowami), wyjazdy na grzyby i jagody, wycieczki piesze i rowerowe, turystyka i edukacja przyrodnicza (zajęcia dydaktyczne i artystyczne w ośrodkach edukacji przyrodniczo-leśnej/ekologicznej), szkolenia i konferencje, turystyka wodna (kapiele, spływy kajakowe, wyjazdy na żagle itd.), zajęcia
The author understands 'silvarecreation' (Latin silva - forest) - forest recreation - to be all the forms of leisure time activity undertaken in a forest which do not disturb the natural rhythm of plant and animal life, and additionally raise ecological awareness in society as well as strengthen the sense of a need to protect nature. 'Silva-tourism', i.e. forest tourism, is the free time activity, for a minimum of one day, in a forest environment, in order to rest, learn, develop interests and for other purposes.

The term 'silva-recreation' subsumes 'silva-tourism', and all its forms can be included in a group of tourism activities based on the principles of eco-development in rural areas, as well as in city forests and forest parks. If we take into consideration the criterion of space, the concept subsuming silva-tourism and silva-recreation will be rural tourism; and if we consider the criterion of the environment, a yet higher concept will be that of sustainable tourism. As for the other terms regarding nature-related tourism, it was noticed that their range of meanings largely overlap with the concepts of silva-tourism and silvarecreation.

In tourism terminology there are many definitions of the various forms of tourism, as well as attempts to classify them. There may appear a doubt whether it is necessary to introduce two new terms. In the author's opinion, their introduction is justified because they cover all tourist behaviour in the forest environment.

Free time activities in a forest area form a vast and varied group. Natural forest assets invite such forms of silvarecreation as residential summer holidays, summer camps for children and teenagers (including hiking and survival camps), hunts (in the literal sense, as well as 'bloodless' hunts), mushroom and bilberry picking, walking and cycling trips, nature tourism and education (educational and art classes in ecological education centres), training sessions, conferences, water tourism (swimming, kayaking, sailing), sports activities and 
i zawody sportowe (biegi przełajowe, biegi na orientację, narciarstwo biegowe itd.), pikniki na zagospodarowanych polanach leśnych i wiele innych. Dzięki istniejącemu zagospodarowaniu turystycznemu, obejmującemu różnorodne obiekty bazy noclegowej i towarzyszącej, np. ośrodki wypoczynkowe, kwatery myśliwskie, ścieżki przyrodniczo-leśne, czy miejsca biwakowania - lasy mogą być miejscem pobytu zarówno w czasie jednodniowych wycieczek, jak również podczas dłuższych wyjazdów.

Do podstawowych atutów, sprzyjających rozwojowi turystyki i rekreacji w lasach, należą wysokiej jakości walory turystyczne środowiska leśnego w Polsce - wypoczynkowe, krajobrazowe i specjalistyczne - a także obecność różnorodnej i rozbudowanej leśnej bazy turystycznej, zwłaszcza noclegowej i edukacyjnej (LISOWSKA 2003). competitions (cross-country running, orienteering, cross-country skiing, etc.), picnics in forest clearings, and many others. Thanks to the existing tourist infrastructure, which includes a variety of lodgings and facilities, e.g. holiday centres, hunting huts, nature trails and campsites, forests may be visited during both one-day and longer trips.

Among the main assets enhancing the development of tourism and recreation in forests are the high quality tourism assets of the forest environment in Poland - recreational, landscape and purpose-specific - as well as the varied and well-developed tourist infrastructure, especially hotel and education related (LisOWSKA 2003).

\section{BIBLIOGRAFIA - BIBLIOGRAPHY}

BoguCKI J., Woźniak A., Zatek W., 1995, Proekologiczne tendencje $w$ turystyce. Agroturystyka i ekoturystyka, [w:] Turystyka i rekreacja jako czynnik integracji europejskiej, AWF, Poznań.

DRZEWIECKI M., 2001, Podstawy agroturystyki, Oficyna Wydawnicza Ośrodka Postępu Organizacyjnego, Bydgoszcz.

Gadant J., 1987, Aménagement et développement rural. Le tourisme vert. Technique et documentation, Paris.

GolembSkI G., 2002, Pojecie $i$ cel zintegrowanego zarzadzania jakościa $w$ regionach, [w:] G. Golembski (red.), Kompendium wiedzy o turystyce, PWN, Warszawa.

KAlAORA B., 1993, Le musée vert. Radiographie du loisir en forêt, L'Harmattan, Paris.

KowALCZYK A., 2001, Geografia turyzmu, Wyd, Uniwersytetu Warszawskiego. Warszawa.

Kryteria kategoryzacji wiejskiej bazy noclegowej - wskazówki dla kwaterodawców, 1998, Federacja Turystyki Wiejskiej „Gospodarstwa Gościnne”, Warszawa.

Lisowska A., 2003, Atrakcyjność turystyczna Lasów Państwowych na Pomorzu Zachodnim, maszynopis pracy magisterskiej, Katedra Geografii Miast i Turyzmu, Uniwersytet Łódzki, Łódż.
MEDLIK S., 1995, Leksykon podróży, turystyki $i$ hotelarstwa, PWN, Warszawa.

Polityka leśna państwa, 1996, Ministerstwo Ochrony Środowiska, Zasobów Naturalnych i Leśnictwa, Warszawa.

Stownik jezyka polskiego, 2006, PWN, Warszawa.

STOcki J., 2001, Leśne obiekty wypoczynkowe $w$ turystycznym zagospodarowaniu lasów, „Postępy Techniki w Leśnictwie", nr 78.

SZUJECKI A., 1997, Leśnictwo a wyzwania cywilizacyjne XXI wieku, [w:] Kongres Leśników Polskich, 24-26 kwietnia 1997. Materiaty $i$ dokumenty, t. I, Warszawa.

SzwichtenBerG A., 1998, Pojmowanie turyswtyki wiejskiej $w$ Polsce $i$ na świecie, „Acta Universitatis Lodziensis. Turyzm", t. 8, z. 1 .

Ustawa z dnia 28 września 1991 r. o lasach, DzU 1991, nr 101, poz. 444, wraz z późniejszymi zmianami.

WARSZYŃSKA J., JACKOWSKI A., 1979, Podstawy geografii turyzmu, PWN, Warszawa.

ZAREBA D., 2001, Ekoturystyka - wyzwania i nadzieje. PWN, Warszawa 2000. 